Sixth Meeting, 12th May 1905.

Mr W. L. Thomson, President, in the Chair.

\title{
Bibliography of the Envelope of the Wallace Line (the three-cusped Hypocycloid).
}

\author{
By J. S. MACKAT, M.A., LL.D.
}

This bibliographical note was drawn up to accompany $\mathrm{Mr}$ Collignon's memoir Recherches sur l'Enveloppe des Pédales des divers points d'une Circonférence par rapport à un triangle inscrit, printed in this volume, p. 2-34; and if I had remembered (as I ought to have done) the very full bibliography given in L'Intermédiaire des Mathématiciens (Vol. 3, p. 166-168, 1896) by Mr Brocard and others, I should not have commenced it. The result, howerer, has been that several articles on this particular curve, not noted in the Intermédiaire, have been discovered, and $I$ have thought it worth while to print the information thus gained.

Reference should also be made to the Intermédiaire, Vol. 1, p. 13-15, 159, 174-176 (1894), Vol. 3, p. 141-143 (1896), Vol. 5, p. 8-9 (1898), Vol. 8, p. $265-266$ (1901).

The Wallace line was discovered about 1799 or 1800 .

See Leybourn's Mathematical Repository (old series), Vol. 2, p. 111.

The discovery of this line is very frequently and erroneousiy attributed to Robert Simson of Glasgow. The reasons for attributing the discovery of the line to Wallace and not to Simson will be found in an article in the Proceedings of the Edinburgh Mathematical Society, Vol. 9, p. 83-91 (1891).

\section{$1856-1866$}

In 1857 there appeared in Crelle's Journal, Vol. 53, p. 231-237, an article by Jacob Steiner, Über eine besondere Curve dritter Klasse (und vierten Grades). It had been read at the Berlin Academy of Sciences on the 7 th of January 1856. Steiner merely enunciates properties of the curve, the three-cusped hypocycloid, without giving demonstrations or diagrams. 
This article has been republished in Steiner's Gesammelte Werke, Vol. 2, p. 641-647 (1882), and an abridgment of it in English will be found in Mathematical Questions with their Solutions from the "Educational Times," which is generally referred to as E.T. R. (Educational Times Reprint), Vol. 3, p. 97-100 (1865).

Also in $185 \overline{7}$ there appeared in Crelle's Journal, Vol. 54, p. 31-47, an article by $\mathrm{H}$. Schröter of Breslau, Über die Erzeugnisse krummer projectivischer Gebilae. "Schröter noticed that the threecusped quartic of Steiner was also the envelope of the connector of corresponding points of two anharmonically corresponding systems, one on a circle, the other on the line at infinity; and herce he was led to interesting generalisations."

In the Lady's and Genileman's Diary for 1860, p. 72 , the prize question proposed for solution by "Petrarch" is :

If an hypocycloid has the radius of its describing circle one-third of that of its base, being thus composed of three branches, and a straight line equal to twice the diameter of the small circle be placed with its extremities on two of the branches, it will touch the third branch.

In the Lady's and Gentleman's Diary for 1861, p. 70-72, two solutions of the prize question are given, and three properties, due to Stephen Watson of Haydonbridge, are appended :

(1) Two tangents to the curve being drawn at right angles, the locus of their intersection is the circle which touches the three branches.

(2) Two normals being drawn at right angles, the locus of their intersection is the fixed circle.

[The enunciation of the third property would require a diagram.]

In the Lady's and Gentleman's Diary for 1862, p. 65, Stephen Watson proposes the question :

If $A$ denote the area of the locus of the intersection of two tangents to the hypocycloid of three branches, making a given angle a with each other, and $A^{\prime}$ that of the corresponding normals; then will $A^{\prime}=9 A$ whatever be the value of $a$. And when $a=60^{\circ}, A^{\prime}$ and $A$ become equal to the areas of the fixed and rolling circles respectively.

Three solutions of the question are given in the Diary for 1863, p. 59-62.

In Crelle's Journal, Vol. 64, p. 101-123 (1865) there is an article: "Sur l'hypocycloide à trois rebroussements," by Cremona. 
It is dated Bologna, 10th May 1864. All Steiner's properties are there demonstrated and some others are added.

In the same Journal, Vol. 66, p. 344-362 (1866) there is an article by Herr Siebeck, "Ueber die Erzeugung der Curven dritter Klasse und vierter Ordnung durch Bewegung eines Punktes."

$$
1865-1878
$$

\section{Educational Times Reprint (E.T.R.)}

In Vol. 3, p. 81-82 (1865) W. K. Clifford gives a solution of the question (proposed by H. R. Greer) :

To find the envelope of the straight line joining the feet of the perpendiculars drawn on the sides of a triangle from a point in the circuinference of the circumscribed circle.

In Vol. 4, p. 13-17 (1866) the Rev. R. Townsend has an article showing that nearly all the interesting results obtained by Steiner with respect to this envelope may be deduced from the two following properties of the hypocycloid of three cusps :

(1) The chord intercepted by the inscribed circle on any tangent to the curve is trisected externally at its point of contact with the curve.

(2) The two arcs into which the inscribed circle is divided by any tangent to the curve are trisected internally at their points of contact with the corresponding branches of the curve.

In Vol. 4, p. 58-59 (1866) Mr Morgan Jenkins has a short article "On the regular tricusped hypocycloid" in which he discusses its evolute, radius of curvature, length of curve and area.

In Vol. 29, p. 80-83 (1878) the question is again raised "Required the envelope of the Simson line," and three different solutions are given, the first by $\mathrm{Mr}$ R. F. Davis, the second by Mr W. J. C. Sharp and others, the third by Christine Ladd, Elizabeth Blackwood and others.

In a recent letter to me Mr Davis makes the remark: "I have found that a great many cases in which the tricusp oceurs as an envelope depend upon this simple fact:

If $A$ be a fixed point on a given circle, and $P Q$ a variable chord having a fixed direction, then the envelope of $Q R$ (drawn parallel to $A P)$ is a tricusp concentric with and circumscribing the given circle."

See also Vol. 34, p. 38, and Vol. 52, p. 69. 
$1866-1868$

Quarterly Journal of Mathematics

In Vol. 7, p. 70-74 (1866), Henry R. Greer has an article entitled "The Geometry of the Triangle. On the equation of a certain envelope."

In Vol. 8, p. 209-211 (1867), N. M. Ferrers gives an "Investigation of the envelope of the straight line joining the feet of the perpendiculars let fall on the sides of a triangle from any position in the circumference of the circumscribed circle."

In Vol. 9, p. 31-41, 175-176 (1868), Cayley has a memoir "On a certain envelope depending on a triangle inscribed in a circle."

\section{$1866-1885$ \\ Giontale di Matematiche \\ (BATTAGLiNI)}

In Vol. 4, p. 214-222 (1866), G. Battaglini, "Sopra una curva di terza classe et di quarto ordine."

In Vol. 23, p. 263-284 (1885), Mr Carmelo Intrigila, "Studio geometrico sull'ipocicloide tricuspide."

\section{9-1902}

\section{Nouvelles Anvales de Mathématiques}

In Vol. 8 (second series) p. 45 (1869) Mr H. Brocard proposes the question:

On donne un cercle $C$ tangent à une droite $D$ en $O$. D'un point $M$ de la circonférence on mène $M A$ perpendiculaire $\dot{a} O D$, et l'on prend $A B=A O$. On joint $B M$, et l'on demande l'enveloppe de la droite $B M$ quand le point $M$ se déplace sur la circonférence. L'enveloppe cherchée admet trois axes de symétrie et trois points de rebroussement remarquables.

Solutions to the question will be found in the same volume p. 418-420, and $470-472$.

In Vol. 9 (second series) p. 73-84 (1870), Paul Serret, "Sur un Théorème de $M$. Ferrers."

In Vol. 9 (second series), p. 202-211, 256-270 (1870), L. Painvin, "Note sur l'hypocycloïde à trois rebroussements." This note was communicated to the editors in July 1865.

In Vol. 9 (second series) p. 254-256 (1870), E. Laguerre, "Extrait d'une lettre adressée à M. Bourget."

In Vol. 9 (second series), 472 (1870), O. Callaudreau, "Thébrèmes sur l'hypocycloïde à trois rebroussements." 
In Vol. 14 (second series) p. 21-31 (1875), Ch. Ph. Cahen, "Sur l'hypocycloïde à trois rebroussements."

In Vol. 18 (second series) p. 33-35 (1879), Mr Badoureau, "Enveloppe de la droite de Simpson" [sic].

In Vol. 18 (second series) p. 57-67 (1879), E. Laguerre, "Sur quelques propriétés des foyers des courbes algébriques et des focales des cones algébriques."

In Vol. 6 (third series) p. 257-266 (1887), Mr Ernest Cesaro, "Sur la droite de Simson."

In Vol. 12 (third series) p. 37-65 (1893), Mr G. Humbert, "Sur l'orientation des systèmes de droites."

In Vol. 14 (third series) p. 297-304 (1895), Mr André Cazamian, "Sur les cubiques unicursales."

In Vol. 1 (fourth series) p. 168-171 (1901), E. Duporeq, "Sur l'hypocycloide à trois rebroussements."

In Vol. 2 (fourth series) p. $206-217$ (1902), M. Fréchet, "Sur quelques propriétés de l'hypocycloïde à trois rebroussements."

\section{$1870-1874$ \\ ZEITSCHRIFT FÜR \\ Mathematik und Physik}

In Vol. 15, p. 129-134 (1870), F. E. Eckhardt, " Einige Sätze über die Epicycloide und Hypocycloide."

In Vol. 17, p. 129-146 (1872), Dr L. Kiepert, "Ueber Epicycloiden, Hypocycloiden, und daraus abgeleitete Curven."

In Vol. 18, p. 363-386 (1873), Wilhelm Frahm, "Ueber die Erzeugung der Curven dritter Classe und vierter Ordnung."

In Vol. 19, p. 115-137 (1874), Milinowski, "Ueber die Steiner'sche Hypocycloide mit drei Rückkehrpunkten."

$$
\text { 1873-1879 }
$$

BULLETIN DE LA

Société Mathématique de France

In Vol. 1, p. 224-226 (1873), Mr H. Brocard, "Démonstration de la proposition de Steiner relative à l'enveloppe de la droite de Simson."

In Vol. 5, p. 18-19 (1877), Mr H. Brocard, "Sur l'enveloppe de la droite de Simpson" [sic]

In Vol. 7, p. 108-123 (1879), E. Laguerre, "Sur quelques propriétés de hypocycloïde à trois points de rebroussement." 
$1873-1883$

Prockedings of the London Mathematical Society

In Vol. 4, p. 321-327 (1873), Professor Wolstenholme on "Epicycloids and Hypocycloids."

In Vol. 14, p. 56-62 (1883), R. A. Roberts on "Polygons circumscribed about a Tricuspidal Quartic."

\section{$1884-1898$ \\ Journal de Mathématiques Spéciales}

In this Journal, edited first by J. Bourget and then by Mr G. De Longchamps, the following articles on the three-cusped hypocycloid will be found :

\section{4, Vol. 3 (second series)}

Mr Weill, "Note sur la droite de Simson," p. 11-16, 30-35, $57-62$.

Mr G. De Longchamps, "Sur l'hypocycloide à trois rebroussements," p. 169-178.

Mr Hadamard, p. 226-232.

1887, Vol. 1 (third series)

Mr G. De Longchamps, "Sur le Trifolium," p. 203-205, 220-223.

1889, Vol. 3 (third series)

$\mathrm{Mr} \mathrm{G}$. De Longchamps in reply to a letter from Mr E. Lemoine, p. 252-254.

1891, Vol. 5 (thïd series)

Mr H. Brocard, "Le Trifolium," p. 32-42, 56-64, 106-115, 123-132, 149-157, 177-181.

1892, Vol. 1 (fourth series)

Mr P. Delens, "Note sur l'hypocycloïde à trois rebroussements et sur les quartiques de troisième classe," p. 193-198.

1893 , Vol. 2 (fourth series)

Mr F. Balitrand, "Aires des hypocycloïdes à trois ou à quatre rebroussements," p. 75-77.

Mr F. Balitrand, "Sur le déplacement d'une figure plane," p. 106-113.

$$
\text { 1894, Vol, } 3 \text { (fourth series) }
$$

Mr F. Balitrand, "Quelques problèmes sur les coniques qui passent par quatre points fixes," p. 73-78, 97-101.

$\mathrm{Mr}$ A. Cazamian, "Théorèmes sur l'hypocycloide à trois rebroussements," p. 78-79. 
1896, Vol. 5 (fourth series)

Mr Ch. Michel, "Sur les courbes unicursales du deuxième et du troisième ordre," p. 265-269.

\section{7, Vol. 1 (fifth series)}

Continuation of Mr Ch. Michel's article, p. 3-7, 25-28, 49-51.

Mr E. Lauvernay, "Sur la polaire de l'hypocycloïde à trois rebroussements," p. 169-177, 193-204.

Mr. Ch. Michel, "Nouveaux théorèmes sur l'hypocycloïde à trois rebroussements," p. 182-186, 204-206.

\section{5-1896}

\section{Proceedings of the Edingurgh Mathematical Society}

In Vol. 3, p. 77-93 (1885), Mr John Alison, "The so-called Simson-line."

In Vol. 14, p. 122-126 (1896), Professor J. E. A. Steggall, "On the envelope of the Simson line of a polygon."

\section{9}

S. Kantor, "I'ie Tangentengeometrie an der Steiner'schen Hypocycloide" in Sitzungsberichte...der Akademie der Wissenschaften (Vienna), Vol. 78, 2nd Division, p. 204-233 (1879).

See also by the same author, "Quelques théorèmes nouveaux sur l'hypocycloide à trois rebroussements" in Bulletin des Sciences Mathématiques, Vol. 3 (second series), p. 136-144 (1879).

\section{$1882-1894$ \\ Mathesis}

In Vol. 2, p. 106-108, 122-127 (1882), Mr Barbarin "Sur la droite de Simson."

In Vol. 4 (second series), p. 62-67, 81-84 (1894), Mr F. Balitrand, "Applications d'un théorème de Chasles."

\section{3}

Captain P. A. MacMahon, "The three-cusped hypocycloid" in the Messenger of Mathematics, Vol. 12, p. 151-153.

\section{3}

Mr H. P. Nielsen, "Om de usammensatte Kurver af fjerde Orden, som daekke sig selv ved en tredie Del af en hel Omdrejning om Begyndelsespunktet" in the Danish journal Nyt Tidsskrift for Matematik, Section B, Vol. 4, p. 30-34. 
1893-1895

\section{Monatshefte für Mathematik und Physik}

In Vol. 4, p. 99-115 (1893), Mr G. Stiner, "Metrische Eigenschaften der Curven dritter Ordnung nit einen Doppelpunkt."

In Vol. 4, p. 135-147 (1893), Mr O. Rupp, "Ueber die mit der Parabelschaar zusammenhängenden Steiner'schen Hypocycloiden."

In Vol. 6, p. 372-374 (1895), Mr G. Stiner, "Zur Construction der Steiner'schen Hypocykloide."

\section{4}

Some remarks on the three-cusped hypocycloid will be found in the solution given by $\mathbf{M r} R$. Gilbert to the question set at the Concours Général de Mathématiques Spéciales (Paris, 1894). See Revue de Mathématiques Spéciales, Vol. 2, p. 357-360 (1894). See also the addition to this solution by Mr A. Pagès in the same Revue, Vol. 3, p. 12-14 (1894). See also in the same Revue, Vol. 5, p. $449-451$ (1900).

1895

Mr W. Godt, "Ueber den Feuerbach'schen Kreis und die Steiner'sche Curve vierter Ordnung und dritter Classe" in the Jahresbericht der Deutschen Mathematiker-Vereinigung, Vol. 4, p. 161-162.

1896

Dr Gino Loria in his work Il passato ed il presente delle principali teorie geometriche (2nd edition, Turin), p. 75 (1896).

Mr W. Godt, "Ueber den Feuerbach'schen Kreis und eine Steiner'sche Curve vierter Ordnung vnd dritter Klasse" in Sitzungsberichte der Akademie der Wissenschaften zu Mïnchen, Vol. 26, p. 119-166 (1896).

$$
1897-1899
$$

\section{Comptes Rendus de L'Académie des Sciences}

Paul Serret has four communications, the first "Sur l'hypocycloïde de Steiner" and the others "Sur l'hypocycloïde à trois rebroussements." Vol. CXXV., p. 404-406,423-426,445-448,459-461 (1897).

S. Kantor, "Réclamations de priorité à l'occasion de plusieurs Notes de M. P. Serret relatives à l'hypocycloïde à trois rebroussements." Vol. CXXVI., p. 928 (1898).

$$
1897-1900
$$

\section{Bulletin de Mathématiqufs Spécialfs}

Mr Ch. Michel, "Théorie synthétique des cubiques à point 
double et des courbes de troisième classe à tangente double." $4^{\mathrm{e}}$ année, p. 97-106 (1897-8), 5e année, p. 1-5, 65-68 (1898-9).

$\mathrm{Mr}$ Ch. Michel, "Sur l'hypocycloide à trois rebroussements." $6^{\bullet}$ année, p. 103-108 (1899-1900).

\section{8}

Dr Bücking, "Die Seitensymmetriegeraden des Dreiecks; als besonderen Fall die Steiner'sche Curve des Dreiecks" in Grunert's Archiv der Mathematik und Physik, Vol. 16 (second series) p. 271-319.

\section{1}

Mr Ferdinando Paolo Ruffini, "Della ipocicloide tricuspide" in Rendiconto della R. Accademia delle Scienze dell' Istituto di Bologna, Vol. 5 (new series), p. 13-23.

\section{2}

Mr A. Gob, "Note sur l'hypocycloide à trois rebroussements" in Mémoires de la Société Royale des Sciences de Liége, Vol. 4 (third series), 7th memoir. Each memoir is paged separately.

\section{2 \\ Johns Hopkins University Circulars}

In Vol. 22, p. 1-3, Mr H. A. Converse, "On the hypocycloids of class three inscribed in a 3-line"; and p. 4-5 "On a system of hypocycloids of class three."

$$
1902-1904
$$

\section{AnNals of Mathematics}

In Vol. 3 (second series), p. 154-160 (1902), Professor R. E. Allardice, "On some curves connected with a system of similar conics."

In Vol. 5 (second series), p. 105-139 (1904), Mr H. A. Converse, "On a system of hypocycloids of class three inscribed in a given 3-line, and some curves connected with it."

In Vol. 5 (second series), p. 169-172 (1904), Professor R. E Allardice, "On a linear transformation and some systems of hypocycloids." 